\title{
Endogenous production of ghrelin and beneficial effects of its exogenous administration in monocrotaline-induced pulmonary hypertension
}

Tiago Henriques-Coelho, Jorge Correia-Pinto, Roberto Roncon-Albuquerque, Jr, Maria J. Baptista, André P. Lourenço, Sílvia Marta Oliveira, Ana Brandão-Nogueira, Antónia Teles, José M. Fortunato and Adelino F. Leite-Moreira

Am J Physiol Heart Circ Physiol 287:H2885-H2890, 2004. First published 26 August 2004;

doi: 10.1152/ajpheart.01122.2003

You might find this additional info useful...

This article cites 38 articles, 20 of which you can access for free at:

http://ajpheart.physiology.org/content/287/6/H2885.full\#ref-list-1

This article has been cited by 4 other HighWire-hosted articles:

http://ajpheart.physiology.org/content/287/6/H2885\#cited-by

Updated information and services including high resolution figures, can be found at: http://ajpheart.physiology.org/content/287/6/H2885.full

Additional material and information about American Journal of Physiology - Heart and Circulatory Physiology can be found at:

http://www.the-aps.org/publications/ajpheart

This information is current as of July 17, 2013.

American Journal of Physiology - Heart and Circulatory Physiology publishes original investigations on the physiology of the heart, blood vessels, and lymphatics, including experimental and theoretical studies of cardiovascular function at all levels of organization ranging from the intact animal to the cellular, subcellular, and molecular levels. It is published 12 times a year (monthly) by the American Physiological Society, 9650 Rockville Pike, Bethesda MD 20814-3991. Copyright (C) 2004 by the American Physiological Society. ISSN: 0363-6135, ESSN: 1522-1539. Visit our website at http://www.the-aps.org/. 


\title{
Endogenous production of ghrelin and beneficial effects of its exogenous administration in monocrotaline-induced pulmonary hypertension
}

\author{
Tiago Henriques-Coelho, Jorge Correia-Pinto, Roberto Roncon-Albuquerque, Jr., \\ Maria J. Baptista, André P. Lourenço, Sílvia Marta Oliveira, Ana Brandão-Nogueira, \\ Antónia Teles, José M. Fortunato, and Adelino F. Leite-Moreira \\ Department of Physiology, Faculty of Medicine, University of Porto, 4200-319 Porto, Portugal
}

Submitted 26 November 2003; accepted in final form 11 August 2004

\begin{abstract}
Henriques-Coelho, Tiago, Jorge Correia-Pinto, Roberto Roncon-Albuquerque, Jr., Maria J. Baptista, André P. Lourenço, Sílvia Marta Oliveira, Ana Brandão-Nogueira, Antónia Teles, José M. Fortunato, and Adelino F. Leite-Moreira. Endogenous production of ghrelin and beneficial effects of its exogenous administration in monocrotaline-induced pulmonary hypertension. Am J Physiol Heart Circ Physiol 287: H2885-H2890, 2004; doi:10.1152/ ajpheart.01122.2003.-We investigated the endogenous production of ghrelin as well as cardiac and pulmonary vascular effects of its administration in a rat model of monocrotaline (MCT)-induced pulmonary hypertension $(\mathrm{PH})$. Adult Wistar rats randomly received a subcutaneous injection of MCT $(60 \mathrm{mg} / \mathrm{kg})$ or an equal volume of vehicle. One week later, animals were randomly assigned to receive a subcutaneous injection of ghrelin $(100 \mu \mathrm{g} / \mathrm{kg}$ bid for $2 \mathrm{wk})$ or saline. Four groups were analyzed: normal rats treated with ghrelin $(n=7)$, normal rats injected with saline $(n=7)$, MCT rats treated with ghrelin $(n=9)$, and MCT rats injected with saline $(n=9)$. At 22-25 days, right (RV) and left ventricular (LV) pressures were measured, heart and lungs were weighted, and samples were collected for histological and molecular analysis. Endogenous production of ghrelin was almost abolished in normal rats treated with ghrelin. In MCT-treated animals, pulmonary expression of ghrelin was preserved, and RV myocardial expression was increased more than 20 times. In these animals, exogenous administration of ghrelin attenuated PH, RV hypertrophy, wall thickening of peripheral pulmonary arteries, and RV diastolic disturbances and ameliorated LV dysfunction, without affecting its endogenous production. In conclusion, decreased tissular expression of ghrelin in healthy animals but not in PH animals suggests a negative feedback in the former that is lost in the latter. A selective increase of ghrelin mRNA levels in the RV of animals with PH might indicate distinct regulation of its cardiac expression. Finally, ghrelin administration attenuated MCT-induced $\mathrm{PH}$, pulmonary vascular remodeling, and RV hypertrophy, indicating that it may modulate $\mathrm{PH}$.
\end{abstract}

myocardial hypertrophy; ventricular hemodymamics; pulmonary vasculature

PULMONARY HYPERTENSION (PH) is a progressive disease associated with right ventricular (RV) hypertrophy that commonly progresses to heart failure. Endothelin (ET)-1 and several other neurohumoral agents play a central role in the complex pathophysiology of PH $(11,28)$ and are used as therapeutic targets for this entity. For instance, several authors observed that ET-1 antagonism decreases $\mathrm{PH}$, restores endothelial metabolic function, inhibits RV hypertrophy, and improves survival both in experimental $(5,19,26)$ and clinical $(27)$ settings.

Ghrelin (Ghr) is an endogenous ligand for the growth hormone $(\mathrm{GH})$ secretagogue receptor (GHSR), originally isolated

Address for reprint requests and other correspondence: A. F. Leite-Moreira, Dept. of Physiology, Faculty of Medicine, Univ. of Porto, 4200-319 Porto, Portugal (E-mail: amoreira@med.up.pt). from the rat stomach (17). Acting on hypothalamopituitary GHSR type 1a, Ghr induces a potent release of GH. Various experimental studies have shown that the $\mathrm{GH} /$ insulin growth factor (IGF)-1 axis improves cardiac function both in normal and failing hearts $(6,8,38)$, although human trials revealed contradictory results about the value of $\mathrm{GH}$ in heart failure therapy $(9,12,31)$.

However, Ghr is much more than an endogenous GH secretagogue and has important direct cardiovascular effects. Ghr administration reduces cardiac afterload and increases cardiac output without increasing heart rate in both normal subjects and patients with dilated cardiomyopathy $(20,21)$. In addition, Ghr has potent vasodilator properties that are endothelium and GH independent $(23,37)$. The Ghr-GHSR signaling pathway is, therefore, presumably involved in the regulation of vascular tone $(21,37)$. There is increasing evidence supporting the hypothesis that cardiovascular effects of $\mathrm{Ghr}$ are mediated by multiple receptors, some of them still to be identified $(2,3)$.

The present study investigated the production of Ghr in the stomach, lung, and RV of normal rats and rats with monocrotaline (MCT)-induced pulmonary hypertension as well as the effects of its chronic administration in both groups. Our hypothesis was that Ghr production could be altered in $\mathrm{PH}$ and that its administration might have beneficial effects by improving cardiac and/or pulmonary vascular structure and function.

\section{METHODS \\ Experimental Design}

Animal experiments were performed according to the Portuguese law for animal welfare and conform to the National Institutes of Health Guide for the Care and Use of Laboratory Animals (NIH Pub. No. 85-23, Revised 1996). Adult male Wistar rats (Charles River Laboratories; Barcelona, Spain) weighing 180-200 g were housed in groups of 5 rats/cage in a controlled environment under a 12:12-h light-dark cycle at a room temperature of $22^{\circ} \mathrm{C}$, with a free supply of food and water. Rats randomly received a subcutaneous injection of MCT (60 mg/kg body wt, Sigma; Barcelona, Spain) or an equal volume of vehicle $(1 \mathrm{ml} / \mathrm{kg}$ body wt). One week later, animals were randomly assigned to receive a subcutaneous injection of $\mathrm{Ghr}(100$ $\mu \mathrm{g} / \mathrm{kg}$ bid for $2 \mathrm{wk}$ ) or saline. The first five residues of Ghr with the large hydrophobic group on the $\mathrm{Ser}^{3}$ side chain are sufficient to maintain the activity of endogenous Ghr (4). An active fragment of Ghr was obtained from Peptides (PGH-3628-PI, human, rat, 1-5), with a functional assay activation at $10 \mathrm{nM}$, relative to Ghr of $96 \pm$ $7 \%$. This protocol resulted in four groups: normal rats treated with Ghr (sham-Ghr, $n=7$ ), normal rats injected with saline (sham, $n=$

The costs of publication of this article were defrayed in part by the payment of page charges. The article must therefore be hereby marked "advertisement" in accordance with 18 U.S.C. Section 1734 solely to indicate this fact. 
7), MCT-treated rats treated with Ghr (MCT-Ghr, $n=9$ ), and MCT-treated rats injected with saline (MCT, $n=9$ ).

\section{Survival Studies}

Analysis of survival rates was performed with another protocol, where two doses of MCT (50 or $60 \mathrm{mg} / \mathrm{kg} \mathrm{sc}$ ) and two doses of Ghr (100 or $200 \mu \mathrm{g} / \mathrm{kg}$ bid sc) were used. Ghr or saline was injected after day 7 after MCT or vehicle injection. This resulted in nine different groups: 1$)$ sham ( $n=10$; no MCT, no Ghr); 2$)$ sham-Ghr $\operatorname{Gho}_{100}(n=10$; no MCT, $100 \mu \mathrm{g} / \mathrm{kg} \mathrm{Ghr}$; 3) sham-Ghr 200 ( $n=10$; no MCT, 200 $\mu \mathrm{g} / \mathrm{kg} \mathrm{Ghr}) ; 4) \mathrm{MCT}_{50}(n=20 ; 50 \mathrm{mg} / \mathrm{kg} \mathrm{MCT}$, no Ghr $;$ 5) $\left.\mathrm{MCT}_{50}-\mathrm{Ghr}_{100}(n=20 ; 50 \mathrm{mg} / \mathrm{kg} \mathrm{MCT}, 100 \mu \mathrm{g} / \mathrm{kg} \mathrm{Ghr}) ; 6\right) \mathrm{MCT}_{50^{-}}$ $\left.\operatorname{Ghr}_{200}(n=20 ; 50 \mathrm{mg} / \mathrm{kg} \mathrm{MCT}, 200 \mu \mathrm{g} / \mathrm{kg} \mathrm{Ghr}) ; 7\right) \mathrm{MCT}_{60}(n=20$; $60 \mathrm{mg} / \mathrm{kg}$ MCT, no Ghr); 8) $\mathrm{MCT}_{60}-\mathrm{Ghr}_{100}(n=20 ; 60 \mathrm{mg} / \mathrm{kg} \mathrm{MCT}$, $100 \mu \mathrm{g} / \mathrm{kg} \mathrm{Ghr})$; and 9) $\mathrm{MCT}_{60}-\mathrm{Ghr}_{200}(n=20 ; 60 \mathrm{mg} / \mathrm{kg} \mathrm{MCT,} 200$ $\mu \mathrm{g} / \mathrm{kg} \mathrm{Ghr}$ ).

\section{Hemodynamic Studies}

The animals were anesthetized with pentobarbital $(6 \mathrm{mg} / 100 \mathrm{~g}$ ip), placed over a heating pad, and tracheostomized for mechanical ventilation with room air (model 683 Harvard Small Animal Ventilator). Anesthesia was maintained with an additional bolus of pentobarbital ( $2 \mathrm{mg} / 100 \mathrm{~g}$ ) as needed. Under binocular surgical microscopy (Wild M651.MS-D, Leica; Herbrugg, Switzerland), the right jugular vein was cannulated for fluid administration (prewarmed $0.9 \% \mathrm{NaCl}$ solution) to compensate for perioperative fluid losses. The heart was exposed through a median sternotomy, and the pericardium was widely opened. RV and left ventricular (LV) pressures were measured with a 2-Fr high-fidelity micromanometer (SPR-324, Millar Instruments) inserted into the RV and LV cavities, respectively. After complete instrumentation, the animal preparation was allowed to stabilize for $15 \mathrm{~min}$. Hemodynamic recordings were made with respiration suspended at end expiration. Parameters were converted on-line to digital data with a sampling frequency of $1,000 \mathrm{~Hz}$. RV and LV pressures were measured at end diastole and peak systole. Peak rates of $\mathrm{RV}$ and $\mathrm{LV}$ pressure rise $\left(\mathrm{dP} / \mathrm{d} t_{\max }\right)$ and pressure fall $(\mathrm{dP} /$ $\left.\mathrm{d} t_{\min }\right)$ were measured as well. The relaxation rate was estimated with the time constant $\tau$ by fitting the isovolumetric pressure fall to a monoexponential function.

\section{Morphometric Analysis}

Once collection of hemodynamic data was completed, cardiac arrest was induced by the injection of $7.5 \% \mathrm{KCl}$ through the central venous catheter. The heart, lungs, and right gastrocnemius muscle were excised and weighed. The right tibia was also excised and measured using a millimetric ruler. Under binocular magnification ( $\times 3.5)$, the RV free wall was dissected from the LV and weighed separately. Heart, lung, RV, and LV + septal $(\mathrm{LV}+\mathrm{S})$ weights were normalized to body weight, whereas gastrocnemius weight was normalized to tibial length. RV weight was, in addition, normalized to that of $\mathrm{LV}+\mathrm{S}$.
$\mathrm{RV}$ and right lung samples were immersion fixed in $10 \%$ buffered formalin and embedded in paraffin. Sections $7 \mu \mathrm{m}$ thick were cut and stained with hematoxylin and eosin.

$\mathrm{RV}$ free wall specimens were obtained from each heart at midway between the apex and base. Studied samples were photographed with a digital camera, and the muscle fiber area was measured, in each section, using a digital image analyzer (Olympus DP Software version 3.0). These measurements were made directly at $\times 400$ magnification only in muscle fibers whose cross section included a nuclear profile (7). Five sections per sample were photographed, and the area of 10 muscle fibers was measured. The area of the 50 analyzed muscle fibers/sample was then averaged.

Pulmonary specimens of each animal were collected from the lower segments of the upper right lobe. External diameter and medial wall thickness in muscular arteries (12 arteries/lung) were analyzed at $\times 400$ magnification. Orthogonal intercepts were used to generate 8 random measurements of external diameter of the vessels (distance between the external lamina) and 16 random measurements of medial thickness of the vessels (distance between the internal and external lamina). For each artery, medial hypertrophy was expressed as follows: \%wall thickness $=[($ medial thickness $\times 2) /($ external diameter)] $\times 100$.

\section{mRNA Quantification by Real-Time RT-PCR}

Samples were collected from the RV free wall, lung parenquima, and gastric fundus. Total mRNA was extracted through the guanidinium-thiocyanate selective silica-gel membrane-binding method (Qiagen 74124) according to the manufacturer's instructions. Concentration and purity were assayed by spectrophotometry (Eppendorf 6131000.012).

Two-step real-time RT-PCR was used to perform relative quantification of mRNA. For each studied mRNA molecule, standard curves were generated from the correlation between the amount of starting total mRNA and the PCR threshold cycle (second derivative maximum method) of graded dilutions from a randomly selected tissue sample (IGF-1: $r=0.994$; GAPDH: $r=0.993$; Ghr: $r=0.990$ ). For relative quantification of specific mRNA levels, $50 \mathrm{ng}$ of total mRNA from each sample underwent two-step real-time RT-PCR. A melt curve analysis of each real-time PCR and $2 \%$ agarose gels $(0.5 \mathrm{mg} / \mathrm{ml}$ ethidium bromide) was run to exclude primer-dimer formation and assess the purity of the amplification product. Experiments were run in triplicate with a PCR intra-assay variability of $18.4 \%$ and a RT-PCR interassay variability of $21.6 \%$. The GAPDH mRNA level was similar in all groups and was used as an internal control gene. Results of mRNA quantification are expressed in an arbitrary unit $(A U)$ set as the average value of the sham group (sham = 1 AU).

RT $\left(10 \mathrm{~min}\right.$ at $22^{\circ} \mathrm{C}, 50 \mathrm{~min}$ at $50^{\circ} \mathrm{C}$, and $10 \mathrm{~min}$ at $\left.95^{\circ} \mathrm{C}\right)$ was performed in a standard thermocycler (Whatman Biometra 050-901) with a total volume of $20 \mathrm{ml}: 40 \mathrm{U} /$ reaction of reverse transcriptase (Invitrogen 18064-014), 20 U/reaction of RNase inhibitor (Promega

Table 1. Effects of Ghr on somatic and cardiac growth

\begin{tabular}{|c|c|c|c|c|}
\hline & Sham & Sham-Ghr & MCT & MCT-Ghr \\
\hline Heart weight/body weight, $\mathrm{g} / \mathrm{kg}$ & $3.03 \pm 0.06$ & $2.70 \pm 0.07$ & $4.10 \pm 0.12^{*}$ & $3.45 \pm 0.12 * \dagger+$ \\
\hline $\mathrm{RV} / \mathrm{LV}+\mathrm{S}, \mathrm{g} / \mathrm{g}$ & $0.21 \pm 0.01$ & $0.23 \pm 0.01$ & $0.58 \pm 0.03^{*}$ & $0.39 \pm 0.03 * \dagger+\S$ \\
\hline Lung weight/body weight, $\mathrm{g} / \mathrm{kg}$ & $4.60 \pm 0.15$ & $3.85 \pm 0.14$ & $9.69 \pm 0.76^{*}$ & $7.02 \pm 0.55 * \dagger \ddagger$ \\
\hline Gastrocnemius muscle weight/tibial length, $\mathrm{mg} / \mathrm{mm}$ & $36.1 \pm 1.8$ & $43.2 \pm 0.8^{*}$ & $34.2 \pm 1.1$ & $36.6 \pm 0.9 \dagger \S$ \\
\hline
\end{tabular}

Data are means $\pm \mathrm{SE}$. RV, right ventricle; $\mathrm{LV}+\mathrm{S}$, left ventricle plus septum; Ghr, ghrelin; $\mathrm{MCT}$, monocrotaline. $* P<0.05$ vs. sham; $\dagger P<0.05$ vs. sham-Ghr; $\ddagger P<0.05$ vs. MCT, §significant interaction. 
Table 2. Effects of Ghr on hemodynamic parameters

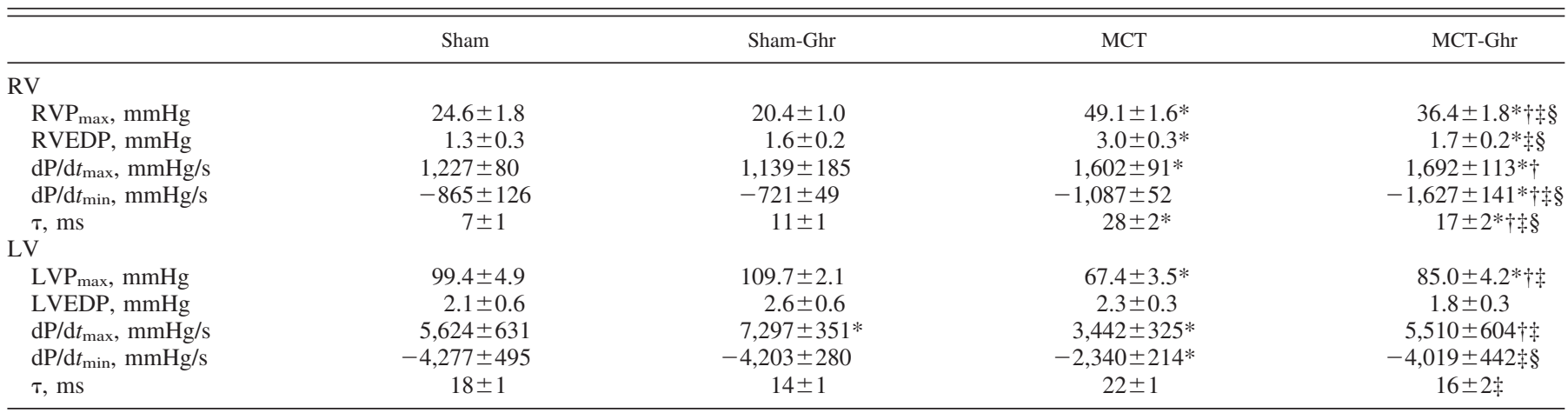

Data are means $\pm \mathrm{SE} . \mathrm{RVP}_{\max }$ and $\mathrm{LVP}_{\max }, \mathrm{RV}$ and LV peak systolic pressures, respectively; RVEDP and LVEDP, RV and LV end-diastolic pressures, respectively; $\mathrm{dP} / \mathrm{d} t_{\max }$ and $\mathrm{dP} / \mathrm{d} t_{\min }$, peak rates of ventricular pressure rise and fall, respectively; $\tau$, time constant. $* P<0.05 \mathrm{vs}$. sham; $\dagger P<0.05 \mathrm{vs}$. sham-Ghr; $\ddagger P<0.05$ vs. MCT; §significant interaction.

$\mathrm{N} 2515), 30 \mathrm{ng} / \mathrm{ml}$ random primers (Invitrogen 48190-011), $0.5 \mathrm{mM}$ nucleotide mix (MBI Fermentas R0192), $1.9 \mathrm{mM} \mathrm{MgCl}_{2}$, and $10 \mathrm{mM}$ DTT. Ten percent of the cDNA yield was used as a template for real-time PCR (Corbett-Research Rotor-Gene 2000) using SYBR green (Qiagen 204143) according to the manufacturer's instructions. Specific PCR primer pairs for the studied genes were as follows: GAPDH, forward 5'-CCG CCT GCT TCA CCA CCT TCT-3' and reverse 5'-TGG CCT TCC GTG TTC CTAS CCC-3'; Ghr, forward 5'-AGG CCA TGG TGT CTT CA-3' and reverse 5'-TTT CTC TGC TGG GCT TTC T-3'; and IGF-1, forward 5'-AGT CTT GGG CAT GTC AGT GTG-3' and reverse 5'-CAG ACG GGC ATT GTG GAT-3'

\section{Statistical Analysis}

Statistical analysis was performed using SPSS 12.0 software.

Group data are presented as means \pm SE and were compared using two-way ANOVA. When the normality test failed, the two-way ANOVA was preceded by a logarithmic transform to obtain a normal distribution. When treatments were significantly different, the Student-Newman-Keuls test was selected to perform pairwise multiple comparisons. Because the study was dominated by early deaths, survival rates were compared not only by the log-rank test but also by the Breslow-Gehan test. Statistical significance was set at $P<0.05$.

\section{RESULTS}

\section{Somatic and Cardiac Growth}

Data related to somatic and cardiac growth are summarized in Table 1. Compared with the sham groups, heart and lung weights were significantly increased in the MCT group. Heart weight augmentation was mainly due to RV growth. Treatment with Ghr attenuated the effects of MCT on cardiac and lung weights, whereas in sham animals it only increased the gastrocnemius weight-to-tibial length ratio. Interaction analysis revealed that effects of Ghr on RV and gastrocnemius weights were significantly different in sham and MCT rats.

\section{$R V$ and LV Hemodynamics}

Hemodynamic data are summarized in Table 2. Peak systolic RV pressure $\left(\mathrm{RVP}_{\max }\right)$, which was used to estimate $\mathrm{PH}$, was significantly increased in the MCT group. Treatment with Ghr markedly attenuated this effect. MCT treatment also significantly increased $\mathrm{RV} \mathrm{dP} / \mathrm{d} t_{\max }, \tau$, and end-diastolic filling pressures. Ghr attenuated MCT effects on $\mathrm{RV} \mathrm{dP} / \mathrm{d} t_{\max }, \tau$, and filling pressures, but not on $\mathrm{dP} / \mathrm{d} t_{\max }$. No effects of Ghr on $\mathrm{RV}$
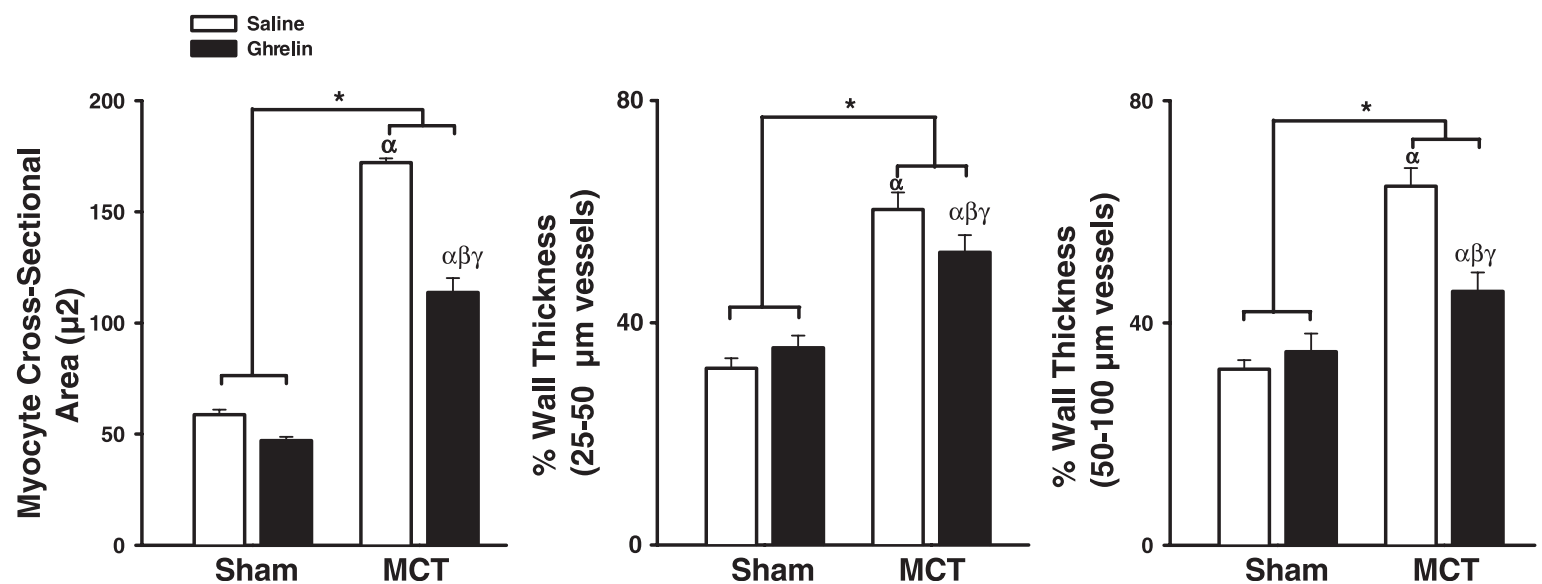

Fig. 1. Mean right ventricular cardiomyocyte cross-sectional area (left) and mean vessel wall thickness of smaller $(25-50 \mu \mathrm{m}$; middle $)$ and larger $(50-100 \mu \mathrm{m}$; right) peripheral pulmonary arteries in sham- and monocrotaline (MCT)-treated animals treated with saline (open bars) or ghrelin (Ghr; solid bars). ${ }^{\alpha} P<0.05$ vs. sham; ${ }^{\beta} P<0.05$ vs. sham-Ghr; ${ }^{\gamma} P<0.05$ vs. MCT; *interaction. 


\section{Right Ventricle}

Lung

Stomach
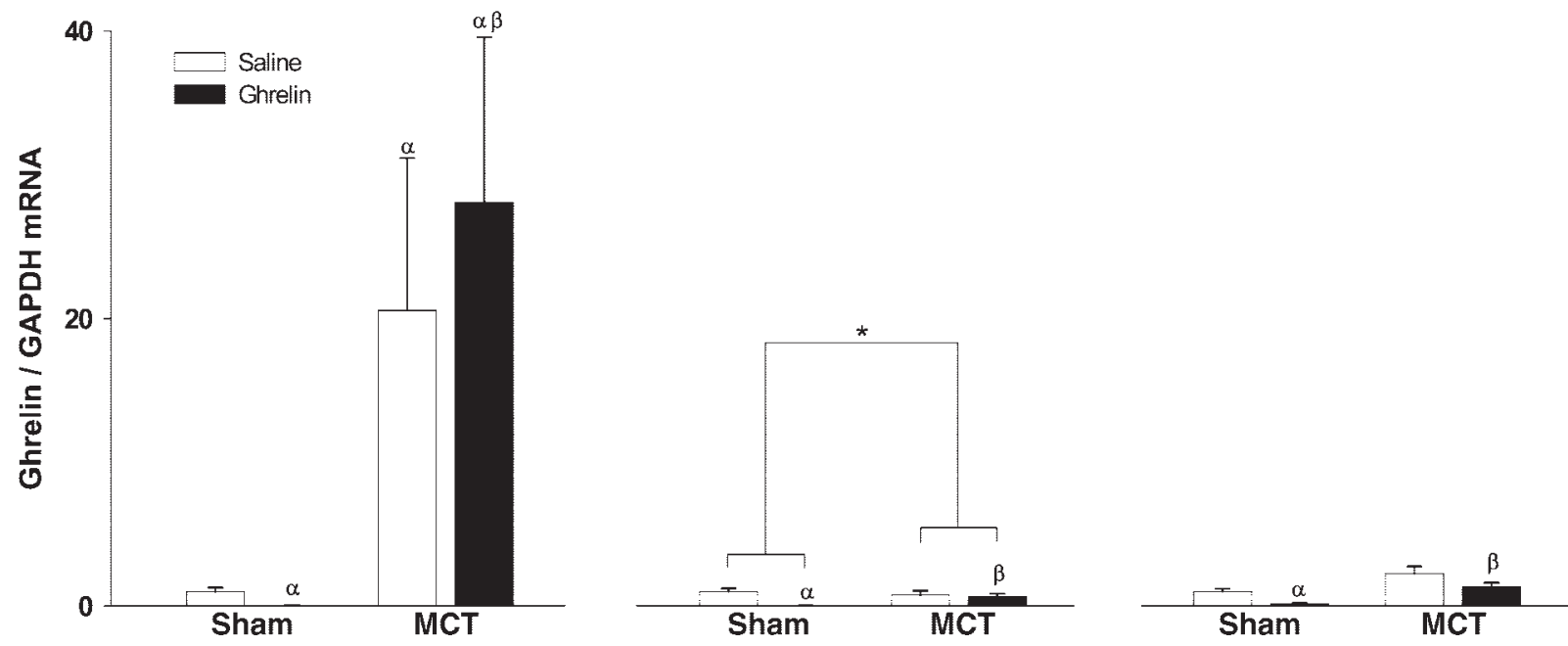

Fig. 2. Right ventricular (left), pulmonary (middle), and gastric (right) mRNA Ghr levels expressed in arbitrary units normalized for GAPDH in sham- and MCT-treated animals treated with saline (open bars) or Ghr (solid bars). ${ }^{\alpha} P<0.05$ vs. sham; ${ }^{\beta} P<0.05$ vs. sham-Ghr; ${ }^{\gamma} P<0.05$ vs. MCT; *interaction.

hemodynamics of sham animals were detected. Effects of Ghr on RV hemodynamics were, therefore, significantly different in sham and MCT animals, as confirmed by interaction analysis.

With regard to the LV, the MCT group presented, compared with the sham group, lower systolic pressures and smaller $\mathrm{dP} / \mathrm{d} t_{\max }$ and $\mathrm{dP} / \mathrm{d} t_{\min }$. Treatment with Ghr blunted all these effects. LV filling pressures and $\tau$ were not significantly altered by MCT, but the latter significantly decreased in the animals treated with Ghr. In sham animals, the only significant effect of Ghr was an increase of $\mathrm{dP} / \mathrm{d} t_{\max }$.

\section{Morphometric Analysis}

RV chronic pressure overload secondary to PH in the MCT group resulted in RV hypertrophy, which was attenuated by Ghr, as expressed by RV/LV + S and RV myocyte crosssectional area (Table 1 and Fig. 1).

Pulmonary vessels showed a significant hypertrophy of the media in the MCT group, which was significantly reduced by Ghr, as illustrated in Fig. 1. This was true both for larger and smaller peripheral arteries.

In sham animals, no significant effects of $\mathrm{Ghr}$ on those parameters were detected. Interaction analysis confirmed that effects of Ghr on such parameters were significantly different in sham and MCT animals.

\section{Real-time RT-PCR Analysis}

Expression of Ghr. The expression of Ghr is shown in Fig. 2. We detected expression of Ghr mRNA in the RV, lung, and gastric fundus of sham animals, but this expression was almost abolished by Ghr treatment. MCT treatment increased the expression of Ghr more than 20-fold in the RV but did not significantly alter it in the lung and gastric fundus. In contrast to sham animals, Ghr administration did not significantly alter expression of its mRNA in MCT-treated rats, although interaction analysis revealed significant differences in the lung.
Expression of IGF-1. The expression of IGF-1 is shown in Fig. 3. Ghr treatment significantly increased IGF-1 mRNA levels in the lung but not in the RV of sham animals. MCT treatment increased IGF-1 mRNA levels both in the RV and lung. In $\mathrm{PH}, \mathrm{Ghr}$ administration normalized $\mathrm{RV}$, but not pulmonary, IGF-1 mRNA expression. Interaction analysis confirmed that Ghr distinctly affects IGF-1 mRNA expression in sham and MCT animals in both the RV and lung.

\section{Survival Analysis}

At the end of the third week, there was a trend for Ghr to dose dependently increase the survival of MCT-injected rats: $\mathrm{MCT}_{50} 70 \%, \mathrm{MCT}_{50}-\mathrm{Ghr}_{100} 80 \%, \mathrm{MCT}_{50}-\mathrm{Ghr}_{200} 90 \%$, $\mathrm{MCT}_{60} 45 \%, \mathrm{MCT}_{60}-\mathrm{Ghr}_{100} 55 \%$, and $\mathrm{MCT}_{60}-\mathrm{Ghr}_{200} 60 \%$.
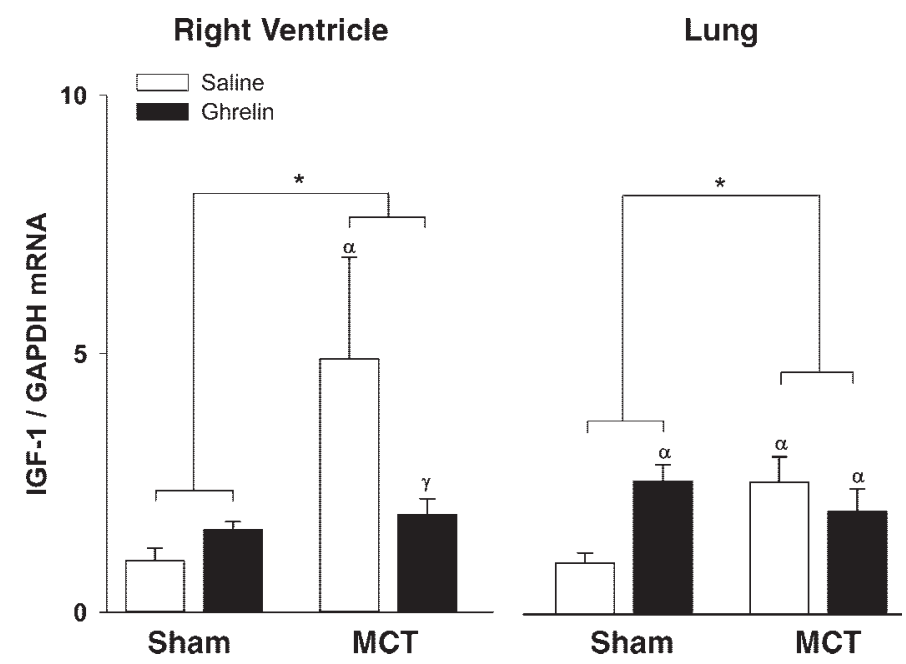

Fig. 3. Right ventricular (left) and pulmonary (right) mRNA IGF-1 levels expressed in arbitrary units normalized for GAPDH in sham- and MCT-treated animals treated with saline (open bars) or Ghr (solid bars). ${ }^{\alpha} P<0.05$ vs. sham; ${ }^{\beta} P<0.05$ vs. sham-Ghr; ${ }^{\gamma} P<0.05$ vs. MCT; *interaction. 
This tendency disappeared, however, at the end of study (day 35 ), with no significant differences in survival, which averaged $9 \pm 2 \%$ in all MCT-treated animals. All sham animals were alive at the end of day 35 .

\section{DISCUSSION}

In the present study, we documented endogenous production of Ghr in the RV, lung, and gastric fundus, which is consistent with previous reports showing production of $\mathrm{Ghr}$ in these organs $(14,17,25)$. Such production was inhibited by exogenous administration of Ghr in healthy animals, suggesting that systemic levels of Ghr might regulate its local production. No deleterious effects were detected as a result of this suppression: these animals had no mortality and cardiac function was normal.

Interestingly, such an ability of systemic Ghr to regulate its local production was apparently lost in $\mathrm{PH}$. Furthermore, in $\mathrm{PH}$, expression of Ghr was markedly increased in the RV but not in the lung and gastric fundus, which might indicate a distinct regulation of its cardiac expression. Given the wellknown vasodilating properties of $\operatorname{Ghr}(21,37)$, one might wonder if its increased production in $\mathrm{PH}$ is not a compensatory response of the RV to increased afterload, to produce a vasodilator substance that could reach the hypertensive lung and locally modify the excess production of vasoconstrictors.

Most actions of Ghr have been explained by stimulation of specific receptors (GHSR-1a), which are responsible not only for its direct effects (e.g., vasodilatation) but also for the indirect effects secondary to GH release $(16,17,24)$. In the present study, we demonstrated that Ghr administration decreased pulmonary hypertension and attenuated RV hypertrophy. Rather disappointing, however, were the modest effects of Ghr on animal survival. In fact, given the impressive effects of Ghr on myocardial and pulmonary vascular remodeling, improved survival was marginal compared with other vasodilating drugs $(5,22,26,29)$, which often have less important pulmonary and cardiac effects.

Potential explanations for the beneficial effects of Ghr include actions both at pulmonary and cardiac levels.

At the pulmonary level, Ghr seems to have a determinant role in fetal lung development (35), whereas the adult human lung is a major source of Ghr mRNA gene expression (13). Additionally, GH segretagogue-binding sites have been demonstrated in the adult lung parenchyma and pulmonary artery wall $(16,24)$. Taking together these evidences with our results, it seems reasonable to propose that $\mathrm{Ghr}$ may modulate $\mathrm{PH}$. The mechanisms for such role include pulmonary vasodilatation and vascular remodeling. Shimizu et al. (30) demonstrated that Ghr improves endothelial dysfunction and increases endothelial nitric oxide synthase expression through a GH-independent mechanism. Because MCT induces endothelial dysfunction, the beneficial effects of Ghr in the lung, as observed in our study, could be due to improvement of pulmonary endothelial function. On the other hand, the Ghr-GHSR signaling pathway can revert ET-1-induced vasoconstriction by mechanisms that act by GH/IGF-1 and endothelium-independent pathways (21, 37). It should be emphasized that ET-1 is increased in PH and seems to be largely involved in MCT-induced PH (10). With regard to pulmonary vascular remodeling, the present study showed that the medial area in peripheral pulmonary arteries was significantly reduced by $\mathrm{Ghr}$, indicating that attenuation of $\mathrm{PH}$ is, at least partially, mediated by this mechanism. This mechanism could also contribute to the effects of Ghr at the pulmonary level.

At the cardiac level, Ghr improved RV and LV hemodynamic, morphological, and molecular parameters. Such improvement might be due either to decreased RV overload or to myocardial actions of Ghr. Decreased RV overload will primarily favor recovery of RV function and structure. With regard to the LV, previous studies also showed that chronic administration of Ghr was able to improve LV dysfunction and to attenuate the development of LV remodeling and cardiac cachexia in rats with heart failure (23).

With regard to the potential role of the GH/IGF1 axis, cardiac production of IGF-1 is increased in RV volume overload and seems to be related with systolic wall stress (15). Additionally, activation of the GH/IGF-1 axis increased myocardial contractility, decreased peripheral vascular resistance $(1,6,8,32,38)$, promoted physiological myocardial hypertrophy (34), and upregulated sarco(endo)plasmic reticulum $\mathrm{Ca}^{2+}$ ATPase 2a (33) in heart failure. In the present study, RV IGF-1 mRNA levels were increased in the MCT group, which might suggest a local increase, dependent of RV overload. Interestingly, treatment with Ghr decreased PH and RV local IGF-1 mRNA levels, which further reinforces a potential load-dependent regulation of cardiac IGF-1 expression. In the lung, IGF-1 levels were increased by $\mathrm{Ghr}$ in sham animals and were similarly elevated in PH. However, in PH, IGF-1 levels were not significantly altered by $\mathrm{Ghr}$, indicating that one cannot explain the observed effects of exogenous Ghr at the pulmonary level by changes in IGF-1 expression.

\section{Limitations of This Study}

Although PH induced by MCT has no equivalent in humans, there are some similarities between this model and some forms of human PH. MCT treatment results in endothelial dysfunction, medial thickness increasing, peripheral artery loss, pulmonary vasculature resistance elevation, and RV hypertrophy that mirror human $\mathrm{PH}(18,36)$.

\section{ACKNOWLEDGMENTS}

The authors are grateful to Dr. Maria Amélia Ferreira, from the Institute of Anatomy of the University of Porto, for scientific support in the morphological studies. We also thank the laboratory technician Manuela Pacheco from the Department of Anatomy for the excellent technical contribution with histological preparations.

\section{GRANTS}

This study was supported by Fundaçaõ para Ciêcia e Tecnologia Grant POCTI/CBO/47519/2002 (partially funded by Fundo Europeu de Desenvolvimento Regional) and the Calouste Gulbenkian Foundation, through Unidade Investigaçaõ \& Desenvolvimento Cardiovascular Grant 51/94-FCT.

\section{REFERENCES}

1. Ambler GR, Johnston BM, Maxwell L, Gavin JB, and Gluckman PD. Improvement of doxorubicin-induced cardiomyopathy in rats treated with insulin-like growth factor I. Cardiovasc Res 27: 1368-1373, 1993.

2. Baldanzi G, Filigheddu N, Cutrupi S, Catapano F, Bonissoni S, Fubini A, Malan D, Baj G, Granata R, Broglio F, Papotti M, Surico N, Bussolino F, Isgaard J, Deghenghi R, Sinigaglia F, Prat M, Muccioli G, Ghigo E, and Graziani A. Ghrelin and des-acyl ghrelin inhibit cell death in cardiomyocytes and endothelial cells through ERK1/2 and PI 3-kinase/AKT. J Cell Biol 159: 1029-1037, 2002. 
3. Bedendi I, Alloatti G, Marcantoni A, Malan D, Catapano F, Ghe C, Deghenghi R, Ghigo E, and Muccioli G. Cardiac effects of ghrelin and its endogenous derivatives des-octanoyl ghrelin and des-Gln14-ghrelin. Eur J Pharmacol 476: 87-95, 2003.

4. Bednarek MA, Feighner SD, Pong SS, McKee KK, Hreniuk DL, Silva MV, Warren VA, Howard AD, Van Der Ploeg LH, and Heck JV. Structure-function studies on the new growth hormone-releasing peptide, ghrelin: minimal sequence of ghrelin necessary for activation of growth hormone secretagogue receptor 1a. J Med Chem 16: 4370-4376, 2000.

5. Chen SJ, Chen YF, Meng QC, Durand J, Dicarlo VS, and Oparil S. Endothelin-receptor antagonist bosentan prevents and reverses hypoxic pulmonary hypertension in rats. J Appl Physiol 79: 2122-2131, 1995.

6. Cittadini A, Grossman JD, Napoli R, Katz SE, Stromer H, Smith RJ, Clark R, Morgan JP, and Douglas PS. Growth hormone attenuates early ventricular remodeling and improves cardiac function in rats with large myocardial infartion. J Am Coll Cardiol 29: 1109-1116, 1997.

7. Douglas PS and Tallant B. Hypertrophy, fibrosis and diastolic dysfunction in early canine experimental hypertension. $J$ Am Coll Cardiol 17: 530-536, 1991.

8. Duerr RL, McKirnan MD, Gim RD, Clark RG, Chien KR, and Ross J Jr. Cardiovascular effects of insulin-like growth factor-1 and growth hormone in chronic left ventricular failure in the rat. Circulation 93: 2188-2196, 1996

9. Fazio S, Sabatini D, Capaldo B, Vigorito C, Giordano A, Guida R, Pardo F, Biondi B, and Sacca L. Preliminary study of growth hormone in the treatment of dilated cardiomyopathy. N Engl J Med 334: 809-814, 1996.

10. Frasch HF, Marshall C, and Marshall BE. Endothelin-1 is elevated in monocrotaline pulmonary hypertension. Am J Physiol Lung Cell Mol Physiol 276: L304-L310, 1999.

11. Gaine SP and Rubin LJ. Primary pulmonary hypertension. Lancet 352: 719-725, 1998.

12. Genth-Zotz S, Zotz R, Geil S, Voigtlander T, Meyer J, and Darius H. Recombinant growth hormone therapy in patients with ischemic cardiomyopathy: effects on hemodynamics, left ventricular function, and cardiopulmonary exercise capacity. Circulation 99: 18-21, 1999.

13. Gnanapavan S, Kola B, Bustin SA, Morris DG, McGee P, Fairclough P, Bhattacharya S, Carpenter R, Grossman AB, and Korbonits $M$. The tissue distribution of the mRNA of ghrelin and subtypes of its receptor, GHS-R, in humans. J Clin Endocrinol Metab 87: 2988-2991, 2002.

14. Iglesias MJ, Pineiro R, Blanco M, Gallego R, Dieguez C, Gualillo O, Gonzalez-Juanatey JR, and Lago F. Growth hormone releasing peptide (ghrelin) is synthesized and secreted by cardiomyocytes. Cardiovasc Res 62: 481-488, 2004

15. Isgaard $\mathbf{J}$, Wahlander $\mathbf{H}$, Adams $\mathbf{M A}$, and Friberg $\mathbf{P}$. Increased expression of growth hormone receptor mRNA and insulin-like growth factor-I mRNA in volume-overload hearts. Hypertension 23: 884-888, 1994.

16. Katugampola S, Pallikaros Z, and Davenport AP. $\left[{ }^{125} \mathrm{I}\right.$-His9]-ghrelin, a novel radioligand for localizing GHS orphan receptors in human and rat tissue; up regulation of receptors with atherosclerosis. Br J Pharmacol 134: 143-149, 2001

17. Kojima M, Hosoda H, Date Y, Nakazato M, Matsuo H, and Kangawa K. Ghrelin is a growth-hormone releasing acylated peptide from stomach. Nature 402: 656-660, 1999.

18. Meyrick B, Gamble W, and Reid L. Development of Crotalaria pulmonary hypertension: hemodynamic and structural study. Am J Physiol Heart Circ Physiol 239: H692-H702, 1980.

19. Miyauchi T, Yorikane R, Sakai S, Sakurai T, Okada M, Nishikibe M, Yano M, Yamaguchi I, Sugishita Y, and Goto K. Contribution of endogenous endothelin-1 to progression of cardiopulmonary alterations in rats with monocrotaline-induced pulmonary hypertension. Circ Res 73: 887-897, 1993.

20. Nagaya $\mathbf{N}$ and Kangawa K. Ghrelin improves left ventricular dysfunction and cardiac cachexia in heart failure. Curr Opin Pharmacol 3: 146-151, 2003.
21. Nagaya N, Kojima M, Uematsu M, Yamagishi M, Hosoda H, Oya H, Hayashi Y, and Kangawa K. Hemodynamic and hormonal effects of human ghrelin in healthy volunteers. Am J Physiol Regul Integr Comp Physiol 280: R1483-R1487, 2001.

22. Nagaya N, Okumura H, Uematsu M, Shimizu W, Ono F, Shirai M, Mori H, Miyatake K, and Kangawa K. Repeated inhalation of adrenomedullin ameliorates pulmonary hypertension and survival in monocrotaline rats. Am J Physiol Heart Circ Physiol 285: H2125-H2131, 2003.

23. Nagaya N, Uematsu M, Kojima M, Ikeda Y, Yoshihara F, Shimizu W, Hosoda H, Hirota Y, Ishida H, Mori H, and Kangawa K. Chronic administration of ghrelin improves left ventricular dysfunction and attenuates development of cardiac cachexia in rats with heart failure. Circulation 104: 1430-1435, 2001.

24. Papotti M, Ghe C, Cassoni P, Catapano F, Deghenghi R, Ghigo E, and Muccioli G. Growth hormone secretagogue binding sites in pheripheral human tissues. J Clin Endocrinol Metab 85: 3803-3807, 2000.

25. Pecker F. Ghrelin in the heart and growth hormone: which is chicken, which is egg? Cardiovasc Res 62: 442-443, 2004.

26. Prie S, Leung TK, Cernacek $\mathbf{P}$, Ryan JW, and Dupuis J. The orally active $\mathrm{ET}_{\mathrm{A}}$ receptor antagonist (+)-S2-(4,6-dimethoxy-pyrimidin-2yloxy)-3-methoxy-3,3-diphenyl-propionic acid (LU 135252) prevents the development of pulmonary hypertension and endothelial metabolic dysfunction in monocrotaline-treated rats. J Pharmacol Exp Ther 282: 13121318, 1997.

27. Rubin LJ, Badesch DB, Barst RJ, Galie N, Black CM, Keogh A, Pulido T, Frost A, Roux S, Leconte I, Landzberg M, and Simonneau G. Bosentan therapy for pulmonary arterial hypertension. $N$ Engl J Med 346: 896-903, 2002.

28. Rubin LJ. Primary pulmonary hypertension. N Engl J Med 336: 111-117, 1997.

29. Schermuly RT, Kreisselmeier KP, Ghofrani HA, Yilmaz H, Butrous G, Ermert L, Ermert M, Weissmann N, Rose F, Guenther A, Walmrath D, Seeger W, and Grimminger F. Chronic sildenafil treatment inhibits monocrotaline-induced pulmonary hypertension in rats. Am J Respir Crit Care Med 169: 39-45, 2004.

30. Shimizu Y, Nagaya N, Teranishi Y, Imazu M, Yamamoto H, Shokawa T, Kangawa K, Kohno N, and Yoshizumi M. Ghrelin improves endothelial dysfunction through growth hormone-independent mechanisms in rats. Biochem Biophys Res Commun 310: 830-835, 2003.

31. Spallarossa P, Rossettin P, Minuto F, Caruso D, Cordera R, Battistini M, Barreca A, Masperone MA, and Brunelli C. Evaluation of growth hormone administration in patients with chronic heart failure secondary to coronary artery disease. Am J Cardiol 84: 430-433, 1999.

32. Stromer H, Cittadini A, Douglas PS, and Morgan JP. Exogenously administered growth hormone and insulin-like growth factor-1 alter intracellular $\mathrm{Ca}^{2+}$ handling and enhance cardiac performance. In vitro evaluation in the isolated isovolumic buffer-perfused rat heart. Circ Res 79: 227-236, 1996.

33. Tajima M, Weinberg EO, Bartunek J, Jin H, Yang R, Paoni NF, and Lorell BH. Treatment with growth hormone enhances contractile reserve and intracellular calcium transients in myocytes from rats with postinfartion heart failure. Circulation 129: 127-134, 1999.

34. Tanaka N, Ryoke T, Hongo M, Mao L, Rockman HA, Clark RG, and Ross J Jr. Effects of growth hormone and insulin-like growth factor-1 on cardiac hypertrophy and gene expression in mice. Am $J$ Physiol 44: 393-399, 1998.

35. Volante M, Fulcheri E, Allia E, Cerrato M, Pucci A, and Papotti M. Ghrelin expression in fetal, infant and adult human lung. J Histochem Cytochem 50: 1013-1021, 2002.

36. Werchan PM, Summer WR, Gerdes AM, and McDonough KH. Right ventricular performance after monocrotaline-induced pulmonary hypertension. Am J Physiol Heart Circ Physiol 256: H1328-H1336, 1989.

37. Wiley KE and Davenport AP. Comparison of vasodilators in human internal mammary artery: ghrelin is a potent physiological antagonist of endothelin-1. Br J Pharmacol 136: 1146-1152, 2002.

38. Yang R, Bunting S, Gillett N, Clark R, and Jin H. Growth hormone improves cardiac performance in experimental heart failure. Circulation 92: 262-267, 1995. 